\title{
Applying Jewish Legal Theory in the Context of American Law and Legal Scholarship: A Methodological Analysis
}

Samuel J. Levine

Follow this and additional works at: https://digitalcommons.tourolaw.edu/scholarlyworks

Part of the Legal Profession Commons, and the Other Law Commons

\section{Recommended Citation}

40 Seton Hall L. Rev. 933 (2010)

This Article is brought to you for free and open access by the Faculty Scholarship at Digital Commons @ Touro Law Center. It has been accepted for inclusion in Scholarly Works by an authorized administrator of Digital Commons @ Touro Law Center. For more information, please contact Iross@tourolaw.edu. 


\title{
Applying Jewish Legal Theory in the Context of American Law and Legal Scholarship: A Methodological Analysis
}

\author{
Samuel J. Levine*
}

\section{INTRODUCTION}

In the past few decades, Jewish legal theory has gained increasing prominence as both an area of study and a field of scholarship in the American legal academy. 'Dozens of American law schools include courses on Jewish law in the curriculum. ${ }^{2}$ Several law schools have established centers dedicated to the study of Jewish law, ${ }^{3}$ while

- Professor of Law, Pepperdine University. As of August 1, 2010, the author will be Professor of Law \& Director of the Jewish Law Institute, Touro Law Center. An earlier version of this Essay was presented as a Plenary Address at the conference Religious Legal Theory: The State of the Field, held at Seton Hall University School of Law, November 12-13, 2009. I thank the conference organizers, Angela Carmella, John Coverdale, and David Opderbeck, for inviting me to address the conference, and I thank the conference participants for helpful comments and conversations. I also thank the faculties at Pepperdine Law School and Touro Law Center for their encouragement. Finally, I thank Fraida Liba, Yehudah, Aryeh, Rachel, and Shira.

1 Samuel J. Levine, Emerging Applications of Jewish Law in American Legal Scholarship: An Introduction, 23 J.L. \& RELIGION 43, 43 \& n.1 (2007).

2 See generally Sherman L. Cohn, Yale Rosenberg: The Scholar and the Teacher of Jewish Law, 39 Hous. L. Rev. 872 (2002); Samuel J. Levine, Teaching Jewish Law in American Law Schools: An Emerging Development in Law and Religion, 26 FORDHAM URB. L.J. 1041 (1999); [hereinafter Levine, Teaching Jewish Law]; Samuel J. Levine, Teaching Jewish Law in American Law Schools-Part II: An Annotated Syllabus, 2 CHI.-KeNT J. INT'L \& CoMP. L. 1 (2002) [hereinafter Levine, Teaching Jewish Law, Part II]; Edward H. Rabin, Symposium: The Evolution and Impact of Jewish Law-Foreword, 1 U.C. DAVIS J. INT'L L. \& POL'Y 49 (1995); Jeffrey I. Roth, Fraud on the Surviving Spouse in Jewish and American Law: A Model Chapter for a Jewish Law Casebook, 28 CASE W. RES. J. INT'L. L. 101 (1996); Alan M. Sokobin, A Program in Comparative Jewish Law, 33 U. TOL. L. REV. 795 (2002).

3 These institutes include The DePaul University College of Law Center for Jewish Law \& Judaic Studies; The Institute of Jewish Law, Boston University School of Law; The Institute of Jewish Law, Touro College/Jacob D. Fuchsberg Law Center; The Yeshiva University Center for Jewish Law and Contemporary Civilization, Cardozo School of Law; and The Tikvah Center for Law \& Jewish Civilization, New York University. See Boston Univ. Sch. of Law, Centers \& Institutes, http://www.bu.edu/ law/directory/centers.html (last visited Mar. 6, 2010); Ctr. for Jewish Law \& Contemporary Civilization at Cardozo Sch. of Law, Yeshiva Univ., 
other schools include discussions of Jewish law as an important component of centers and programs on law and religion. ${ }^{4}$ The prominence of Jewish legal theory in American legal scholarship has been even more pronounced, giving rise to an extensive body of literature exploring both Jewish law on its own terms and its potential applications to American law. ${ }^{5}$

In light of these developments, this Essay briefly considers the current state of the field of Jewish law and Jewish legal theory within the context of the American legal academy. Specifically, the Essay suggests that it may be instructive to step back and focus on a methodological assessment of these developments, taking into account a number of salient features of the Jewish legal model. These aspects of Jewish law both complicate and enrich the application of Jewish legal perspectives to issues of American law and public policy.

First, the Jewish legal system has developed over the course of thousands of years, functioning within a broad range of societal and geographical settings, amidst benign and, all-too-often, belligerent and oppressive circumstances. ${ }^{6}$ This historical experience has re-

http://www.cardozo.yu.edu/cjl/ (last visited Mar. 6, 2010); Ctr. for Jewish Law \& Judaic Studies, DePaul Univ. Coll. of Law, http://www.law.depaul.edu/ centers_institutes/jljs/ (last visited Mar. 6, 2010); Jewish Law Inst., Touro Law Center, $\quad$ http://www.tourolaw.edu/academic_programs/institutes/jewish_law_ institute.asp (last visited Mar. 6, 2010); Tikvah Ctr. for Law \& Jewish Civilization, NYU Institutes on the Park, http://www.nyutikvah.org/ (last visited Mar. 6, 2010).

4 These programs include The Center for the Study of Law and Religion, Emory University School of Law; The Institute on Religion, Law \& Lawyer's Work, Fordham University School of Law; The Herbert and Elinor Nootbaar Institute on Law, Religion, and Ethics, Pepperdine University School of Law. See InST. ON Religion, Law \& LaWYer's WORK, FordHam LaW SCH., Promoting the INTEGRation of Religious VALUES INTO THE PRACTICE OF LAW 1, available at http://law.fordham.edu/ assets/LawReligion/Law_Religion_brochure.pdf; Emory Univ. Sch. of Law, The Center for the Study of Law and Religion: Mission \& History, http://cslr.law.emory.edu/ about-cslr/mission-history/ (last visited Mar. 6, 2010); Pepperdine Univ. Sch. of Law, Herbert and Elinor Nootbaar Institute on Law, Religion, and Ethics, http://law.pepperdine.edu/nootbaar/ (last visited Mar. 6, 2010).

${ }^{5}$ See generally Levine, supra note 1; Samuel J. Levine, Jewish Legal Theory and American Constitutional Theory: Some Comparisons and Contrasts, 24 HASTINGS CONST. L.Q. 441, 442-43 \& nn.3-11 (1997) [hereinafter Levine, Jewish Legal Theory and American Constitutional Theory]; Levine, Teaching Jewish Law, supra note 2; Levine, Teaching Jewish Law, Part II, supra note 2; Suzanne Last Stone, In Pursuit of the Counter-Text: The Turn to the Jewish Legal Model in Contemporary American Legal Theory, 106 HARV. L. REV. 813 (1993).

6 See AN INTROduction to the History and SOURCES Of JeWISH LAW, at xvi (N.S. Hecht et al. eds., 1996); 1 MENACHEm Elon, Jewish LAw: History, SOURCES, PRINCIPLES: Ha-MishPat Ha-IVRI 1 (Bernard Auerbach \& Melvin J. Sykes trans., The Jewish Publ'n Soc'y 1994) (1988). 
sulted in the production of a voluminous library of legal literature, with contributions from virtually every generation and, over time, nearly all parts of the world. ${ }^{7}$ Therefore, an attempt to consider the approach of the Jewish legal system to an issue of significance in the American legal system might require an initial effort to grapple with the various primary and secondary sources of Jewish law that address the issue directly and indirectly. Through the course of millenniaand up to this day-scholars have explored Jewish law on its own terms, providing instrumental and arguably indispensible studies and insights into ways Jewish law might help illuminate contemporary American legal thought.

Second, the Jewish legal system addresses nearly every aspect of human endeavor, from the seemingly mundane to the profound, from ritual to interpersonal activities, from civil and commercial law to criminal law. ${ }^{8}$ The scope of the Jewish legal system not only adds

7 For helpful introductions to the history, sources, and structure of Jewish law, see AN INTRODUCTION TO THE HISTORY AND SOURCES OF JEWISH LAW, supra note 6; IRVing A. BReitowttz, Between Civil LAW and Religious LaW: The Plight of The AGUNAH IN AMERICAN SOCIETY 307-13 (1993); MENACHEM ELON ET AL., JEWISH LAW (MishPaT IVRI): CASES AND MATERLALS (1999); 1 ElON, supra note 6; DAVID M. FEldman, BirTh Control in JeWISH LAW: MARITAL RElations, Contraception, AND ABORTION as SET ForTH In THE Classic Texts OF JeWISH LAW 3-18 (1968); JEWISH LAW AND Legal Theory (Martin P. Golding ed., 1993); ARYEH KaPLAN, THE ARYEH KaPlaA READER 211-19 (1985); AARON KIRSCHENBAUM, EQUITY IN JEWISH LAW: HaLAKHIC PERSPECTIVES IN LAW: FORMALISM AND FLEXIBILITY IN JEWISH CIVIL LAW app. at 289-304 (1991); NaHum Rakover, A Guide to the SOURCes of JeWISH LaW (1994); Aaron M. SCHREIBER, JEWISH LAW AND DECiSION-MAKING: A STUdy Through Time (1979); Menachem Elon, The Legal System of Jewish Law, 17 N.Y.U.J. IN'T'L L. \& POL. 221 (1985); Steven F. Friedell, Aaron Kirschenbaum on Equity in Jewish Law, 1993 BYU L. REV. 909 (book review).

${ }^{8}$ See, e.g., ARyeh KaPlan, The Handbook OF Jewish Thought II 5:61-62, at 78 (1979) ("The . . commandments . . penetrate every nook and cranny of a person's existence, hallowing even the lowliest acts and elevating them to a service to God.... [T] he multitude of laws . . sanctify every facet of life, and constantly remind one of [one's] responsibility toward God."); Joseph B. SOlOveITCHIK, HaLAKHIC MAN 20, 22 (Lawrence Kaplan trans., Jewish Publ'n Soc'y of Am. 1983) (1944) (observing that "[ $t]$ here is no phenomenon, entity, or object in this concrete world" beyond the grasp of halacha, and noting that "just a few of the multitude of halakhic [halachic] subjects" include "sociological creations: the state, society, and the relationship of individuals within a communal context"; "laws of business, torts, neighbors, plaintiff and defendant, creditor and debtor, partners, agents, workers, artisans, bailees"; "[f] amily life"; "[w] ar, the high court, courts and the penalties they impose"; and "psychological problems ....."); id. at 93-94 (explaining that Halacha (i.e., Jewish law) "does not differentiate between the [person] who stands in [the] house of worship, engaged in ritual activities, and the mortal who must wage the arduous battle of life"; rather it "declares that [a person] stands before God not only in the synagogue but also in the public domain, in [one's] house, while on a journey, while lying down 
to the volume of legal material that constitutes the corpus of Jewish law but also serves as a reminder of the underlying religious character of the Jewish legal system, premised upon express and implicit theological principles that infuse and affect the function of the law. ${ }^{9} \mathrm{Al}-$ though it is possible to debate the extent to which, as both a descriptive and normative matter, religion informs American law, ${ }^{10}$ it is not plausible to picture the American legal system as a consciously religious-let alone Jewish-system of law. Therefore, in addition to challenges that generally confront attempts to apply the laws of foreign legal systems in the context of American law," greater challenges

and rising up," and that "[t]he marketplace, the street, the factory, the house, the meeting place, the banquet hall, all constitute the backdrop for the religious life"); Moshe Silberg, Law and Morals in Jewish Jurisprudence, 75 HARV. L. REv. 306, 322 (1961) ("The ... mode of dress, ... diet, dwelling, behavior, relation with [others], . . . family affairs, and . . . business affairs were all prefixed and premolded, in a national cloak, in a set of laws that was clear, severe, strict, detailed, that accompanied [an individual] day by day, from cradle to grave."); see also Samuel J. Levine, The Broad Life of the Jewish Lauyer: Integrating Spirituality, Scholarship and Profession, 27 TEx. TECH L. REV. 1199, 1199 (1996) ("The religious individual faces the constant challenge of reconciling religious ideals with the mundane realities of everyday life. Indeed, it is through the performance of ordinary daily activities that a person can truly observe such religious duties as serving $\mathrm{G}-\mathrm{d}$ and loving one's neighbor.").

${ }^{9}$ See, e.g., Introduction to JEWISH LAW AND LEGAL THEORY, supra note 7, at xiii, xiii; Menachem Elon, The Legal System of Jeruish Law, 17 N.Y.U. J. INT'L L. \& POL. 221, 227 (1985).

${ }^{10}$ For discussions of the relationship between religion and American law and politics, see ROBERT AUdI, RELIGIOUS COMMITMENT AND SECULAR REASON (2000); STEPHEN L. Carter, The Culture of Disbelief: How American law and Politics Trivialize Religious Devotion (1993); Kent Greenawalt, Private Consciences and Public Reasons (1995); Kent Greenawalt, Religious Convictions and Political Choice (1988); Michael J. Perry, love and PoWer: The Role of Religion and Morality in american Polmics (1991); Michael J. Perry, Morality, Polmtics, and Law (1988); Michael. J. Perry, Religion in Politics: Constitutional and Moral Perspectives (1997); RELigion AND ConTEMPORARY Liberalism (Paul J. Weithman ed., 1997); Suzanna Sherry, Religion and the Public Square: Making Democracy Safe for Religious Minorities, 47 DePAul L. ReV. 499 (1998); Symposium, Law and Morality, 1 NOTrE Dame J.L. ETHICS \& PUB. POL'Y 1 (1984); Symposium, Religion and the Judicial Process: Legal, Ethical, and Empirical Dimensions, 81 MARQ. L. REV. 177 (1998); Symposium, Religion in the Public Square, 42 WM. \& MARY L. REV. 647 (2001); Symposium on Religion in the Public Square, 17 Notre Dame J.L. EThics \& PUB. POL'y 307 (2003); Symposium, Religiously Based Morality: Its Proper Place in American Law and Public Policy, 36 WAKE FOREST L. REv. 217 (2001); Symposium, The Role of Religion in Public Debate in a Liberal Society, 30 San Diego L. Rev. 849 (1993); Ruti Teitel, A Critique of Religion as Politics in the Public Sphere, 78 CORNELL L. REV. 747 (1993).

"The ongoing debate among prominent justices, judges, and scholars over reliance on foreign authority in American constitutional interpretation provides a poignant illustration of some of the complexities confronting efforts to apply foreign law in the context of the American legal system. See, e.g., Roper v. Simmons, 543 U.S. 551, 567, 576-78 (2005); id. at 622-28 (Scalia, J., dissenting); Lawrence v. Texas, 539 
may face any effort to apply concepts from a religious legal system, in particular the Jewish legal system.

These characteristics of Jewish law may suggest the need to employ an effective methodology for applying a given principle from Jewish legal theory to American law and public policy. Specifically, such an analysis may require a methodology that: (a) carefully and accurately depicts the principle, as understood within Jewish legal theory, in a way that is faithful to the Jewish legal system; (b) considers carefully the extent to which the principle incorporates theological underpinnings that are particular to the Jewish legal model and, accordingly, may not be suitable in the context of the American legal model; and (c) applies the lessons from the Jewish legal system only to the extent that they make sense within the internal logic of the American legal system, thus remaining faithful to American jurisprudence as well.

This Essay illustrates the promise and potential limitations posed by this methodology through a close look at perhaps the most prominent references to Jewish law in the history of the American legal sys-

U.S. 558, 576-77 (2003); id. at 598 (Scalia, J., dissenting); Atkins v. Virginia, 536 U.S. 304, 316 n.21 (2002); id. at 324-25 (Rehnquist, C.J., dissenting); Roger P. Alford, In Search of a Theory for Constitutional Comparativism, 52 UCLA L. REv. 639 (2005); Stephen Breyer, Assoc. Justice, U.S. Supreme Court, Keynote Address at the NinetySeventh Annual Meeting of the American Society of International Law (Apr. 4, 2003), in 97 AM. SOC'Y INT'L L. PROC. 265, 265-66 (2003); Steven G. Calabresi, “A Shining City on a Hill": American Exceptionalism and the Supreme Court's Practice of Relying on Foreign Law, 86 B.U. L. REV. 1335 (2006); Frank H. Easterbrook, Foreign Sources and the American Constitution, 30 HARV. J.L. \& PUB. POL'Y 223 (2006); David Fontana, Refined Comparativism in Constitutional Law, 49 UCLA L. REV. 539 (2001); Ruth Bader Ginsburg, Assoc. Justice, U.S. Supreme Court, A Decent Respect to the Opinions of [Human]kind: The Value of a Comparative Perspective in Constitutional Adjudication, Keynote Address at the Ninety-Ninth Annual Meeting of the American Society of International Law (Apr. 1, 2005), in 99 AM. SoC'Y INT'L L. Proc. 351, 355 (2005); Vicki Jackson, Constitutional Comparisons: Convergence, Resistance, Engagement, 119 HARV. L. Rev. 109 (2005); Ronald J. Krotoszynski, Jr., "I'd Like To Teach the World To Sing (In Perfect Harmony)": International Judicial Dialogue and the Muses-Reflections on the Perils and the Promise of International Judicial Dialogue, 104 MICH. L. REV. 1321, 132225, 1335-36, 1356-58 (2006); John O. McGinnis, Foreign to Our Constitution, 100 Nw. U. L. REv. 303 (2006); Eric A. Posner \& Cass R. Sunstein, The Law of Other States, 59 Stan. L. Rev. 131 (2006); Richard A. Posner, Foreword: A Political Court, 119 Harv. L. Rev. 31 (2005); Symposium, Global Constitutionalism, 59 STAN. L. REV. 1153 (2007); Mark Tushnet, When Is Knowing Less Better Than Knowing More? Unpacking the Controversy over Supreme Court Reference to Non-U.S. Law, 90 MiNN. L. REV. 1275 (2006); Melissa A. Waters, Getting Beyond the Crossfire Phenomenon: A Militant Moderate's Take on the Role of Foreign Authority in Constitutional Interpretation, 77 FORDHAM L. REV. 635 (2008); Melissa A. Waters, Mediating Norms and Identity: The Role of Transnational Judicial Dialogue in Creating and Enforcing International Law, 93 GEO. L.J. 487 (2005). 
tem: the Supreme Court of the United States's citations to the rule against self-incrimination in Jewish law. ${ }^{22}$ In particular, this Essay

12 See Garrity v. New Jersey, 385 U.S. 493,497 n.5 (1967); Miranda v. Arizona, 384 U.S. 436, $458 \mathrm{n} .27$ (1966). For examples of other American cases citing Jewish law in the context of discussions of self-incrimination, see United States v. Gecas, 120 F.3d 1419, 1425 (11th Cir. 1997); United States v. Huss, 482 F.2d 38, 51 (2d Cir. 1973); Moses v. Allard, 779 F. Supp. 857, 870 (E.D. Mich. 1991); Roberts v. Madigan, 702 F. Supp. 1505, 1517 n.20 (D. Colo. 1989); In re Agosto, 553 F. Supp. 1298, 1300 (D. Nev. 1983); State v. McCloskey, 446 A.2d 1201, 1208 n.4 (N.J. 1982); People v. Brown, 86 Misc. 2d 339, 487 n.5 (N.Y. Nassau County Ct. 1975).

For examples of references to the Jewish law of self-incrimination in American legal scholarship, see LEONARD W. LEVY, ORIGINS OF THE FIFTH AMENDMENT: THE Right AGainst Self-InCRimination 433-41 (2d ed., Macmillan Publ'g Co. 1986) (1968); Albert W. Alschuler, A Peculiar Privilege in Historical Perspective, in R. H. Helmholz et al.,The Privilege Against Self-Incrimination: Its Origins and DEVELOPMENT 181, 279 n.28 (1997); Cheryl G. Bader, "Forgive Me Victim for I Have Sinned": Why Repentance and the Criminal Justice System Do Not Mix -A Lesson from Jewish Law, 31 FordHAM URB. L.J. 69, 88 (2003); Isaac Braz, The Privilege Against SelfIncrimination in Anglo-American Law: The Influence of Jewish Law, in JEWISH LAW AND CuRRENT LeGal Problems 161 (Nahum Rakover ed., 1984); Debra Ciardiello, Seeking Refuge in the Fifth Amendment: The Applicability of the Privilege Against Self-Incrimination to Individuals Who Risk Incrimination Outside the United States, 15 FordHAM INT'L L.J. 722, 725 (1992); Suzanne Darrow-Kleinhaus, The Talmudic Rule Against Self-Incrimination and the American Exclusionary Rule: $A$ Societal Prohibition Versus an Affirmative Individual Right, 21 N.Y.L. SCH. J. INT'L \& COMP. L. 205 (2002); Malvina Halberstam, The Rationale for Excluding Incriminating Statements: U.S. Law Compared to Ancient Jewish Law, in JeWISH LAW AND CuRRENT Legal Problems, supra, at 177; George Horowitz, The Privilege Against Self-Incrimination-How Did It Originate?, 31 TEMP. L.Q. 121, 125 (1958); Samuel J. Levine, An Introduction to Self-Incrimination in Jewish Law, with Application to the American Legal System: A Psychological and Philosophical Analysis, 28 LOY. L.A. INT'L \& COMP. L. REV. 257 (2006) [hereinafter Levine, An Introduction to Self-Incrimination in Jewish Law]; Samuel J. Levine, Miranda, Dickerson, and Jewish Legal Theory: The Constitutional Rule in a Comparative Analytical Framework, $69 \mathrm{MD}$. L. REV. 78 (2009) [hereinafter Levine, Miranda, Dickerson, and Jewish Legal Theory]; Simcha Mandelbaum, The Privilege Against Self-Incrimination in Anglo-American and Jewish Law, 5 AM. J. COMP. L. 115, 116-18 (1956); Irene Merker Rosenberg \& Yale L. Rosenberg, In the Beginning: The Talmudic Rule Against Self-Incrimination, 63 N.Y.U. L. REv. 955 (1988); Aaron M. Schreiber, The Jurisprudence of Dealing with Unsatisfactory Fundamental Law: A Comparative Glance at the Different Approaches in Medieval Criminal Law, Jewish Law and the United States Supreme Court, 11 PACE L. REV. 535, 550 (1991); Daniel J. Seidmann \& Alex Stein, The Right to Silence Helps the Innocent: A Game Theoretic Analysis of the Fifth Amendment Privilege, 114 HARV. L. REV. 431, 452 n.70 (2000); Michelle M. Sharoni, A Journey of Two Countries: A Comparative Study of the Death Penalty in Israel and South Africa, 24 HASTINGS INT'L \& COMP. L. REv. 257, 263 (2001); Erica Smith-Klocek, A Halachic Perspective on the Parent-Child Privilege, 39 CATH. LAw. 105, 109 (1999); Gregory Thomas Stremers, The Self-Incrimination Clause and the Threat of Foreign Prosecution in Bankruptcy Proceedings: A Comment on Moses v. Allard, 70 U. DET. MERCY L. REV. 847, 854-55 (1993); Bernard Susser, Worthless Confessions: The Torah Approach, 130 NEw L.J. $1056(1980)$.

For a general survey and analysis of references to Jewish law in American judicial opinions, see BERNARD J. MEISLIN, JeWISH LAW IN AMERICAN TRIBUNALS (1976); Daniel 
compares the Court's reliance on Jewish law in the landmark 1966 case of Miranda $v$. Arizona, ${ }^{13}$ with the Court's reference to Jewish law less than one year later in Garrity $v$. New Jersey. ${ }^{14}$ This Essay argues that, in contrast to Miranda, which relies upon a largely mechanical reference to religious principles in Jewish law, Garrity employs a more conceptual methodology, exploring the conceptual underpinnings of Jewish law and, accordingly, drawing more insightful lessons to be applied in the context of the American legal system. Building on this distinction, this Essay examines applications of Jewish legal theory in a variety of areas of contemporary American legal scholarship. This Essay concludes that, similar to the Court's approach in Garrity, American legal theory draws important insights from Jewish legal theory through scholarship that employs a conceptual methodology for the application of principles in Jewish law.

\section{MIRANDA V. ARIZONA: LIMITATIONS OF THE APPLICATION OF JEWISH LEGAL THEORY IN AMERICAN LAW}

In the landmark case of Miranda $v$. Arizona, Section II of Chief Justice Earl Warren's majority opinion begins, "We sometimes forget how long it has taken to establish the privilege against selfincrimination, the sources from which it came and the fervor with which it was defended." ${ }^{15}$ Before launching into a historical survey, starting with the events of the Star Chamber in 1637, the opinion asserts that the "roots" of the privilege against self-incrimination "go back into ancient times." The opinion documents this assertion with a footnote stating, "Thirteenth century commentators found an analogue to the privilege grounded in the Bible." ${ }^{17}$ The footnote quotes a translation of a ruling found in Maimonides' Code of Law. "To sum up the matter, the principle that no man is to be declared

G. Ashburn, Appealing to a Higher Authority?: Jewish Law in American Judicial Opinions, 71 U. DET. MERCY L. REV. 295 (1994); Charles Auerbach, The Talmud-A Gateway to the Common Law, 3 W. RES. L. REV. 5 (1951); Bernard J. Meislin, Jewish Law in America, in THE JEWISH LAW ANNUAL: JEWISH LAW IN LEGAL HISTORY AND THE MODERN WORLD (Bernard S. Jackson ed., Supp. II 1980); Bernard J. Meislin, Jewish Law in American Tribunals, 7 ISR. L. REV. 349 (1972).

13384 U.S. 436,458 n. 27.

14385 U.S. 493,497 n.5.

15384 U.S. at 458.

${ }^{16}$ Id.

${ }^{17}$ Id. at 458 n.27. 
guilty on his own admission is a divine decree." ${ }^{18}$ Finally, the footnote concludes: "See also Lamm, The Fifth Amendment and Its Equivalent in the Halakhah, 5 Judaism 53 (Winter 1956)."

Miranda's reliance on Jewish law, in this manner, is notable for a number of reasons. First, Miranda presents us with the phenomenon of one of the most influential Chief Justices of the United States starting a crucial section of the majority opinion of one of the most important Fifth Amendment decisions in the history of the United States-and one of the most famous decisions in any area of lawwith a reference to Jewish law.

Second, the opinion is careful to describe Jewish law on its own terms, quoting directly from Maimonides to provide an accurate depiction of the law within the Jewish legal system. As the quotation makes clear, Jewish law includes an absolute ban on the admissibility of confessions as evidence against criminal defendants. ${ }^{20}$ In further reliance on Maimonides, the opinion accepts the characterization of this rule as ancient, which is consistent with the understanding of the rule within Jewish legal tradition. ${ }^{21}$

Third, in further fidelity to Jewish law, rather than citing to a law review article or the work of an American lawyer, the footnote cites to the work of scholars of Jewish law through the Code of Law of Maimonides, a comprehensive restatement of the entire corpus of Jewish law written by one of the most important Medieval scholars of Jewish law and philosophy, ${ }^{22}$ and an article written by Rabbi Norman Lamm, a leading twentieth century scholar of Jewish law and philosophy and later president of Yeshiva University, less than a decade before Miran$d a$ was decided. ${ }^{23}$

${ }_{18}$ Id. (quoting Laws Concerning the Sanhedrin and the Penalties Within Their Jurisdiction, in THE CODE OF MaImonides (MISHNEH TORAH): BoOK FouRTEen: THE BoOK OF JUDGES treatise 1, ch. 18, I 6, at 53 (3 YALE JUDAICA SERIES, Julian Obermann et al. eds., Abraham M. Hershman trans., 1977) (1949)).

${ }^{19}$ Id. (italics added).

${ }^{20}$ Id.

${ }^{21}$ See Miranda, 384 U.S. at 458 n.27.

${ }^{22}$ For a discussion of Maimonides and the Mishneh Torah, see ISADORE TWERSKY, INTRODUCTION TO THE CODE OF MAIMONIDES (MISHNEH TORAH) (22 YALE JUdAICA SERIES, Leon Nemoy et al. eds., 1980).

${ }^{23}$ For a biography of Rabbi Lamm and a bibliography of his scholarship, see Yeshiva Univ., Our Speakers and Authors: Rosh HaYeshiva Norman Lamm, http://www.yutorah.org/speakers/speaker.cfm/80106/Rosh\%20HaYeshiva_Norma n_Lamm (last visited May 12, 2010). 
Nevertheless, some questions may arise as to the Miranda Court's methodology in applying Jewish law. Miranda famously established the Miranda warnings as a means toward preventing coerced confessions. ${ }^{24}$ The Court delineated in great detail a number of interrogation methods widely in use at the time, finding that the function-if not the design - of many of these methods was to produce conditions under which a suspect was subject to both subtle and more blatant forms of psychological coercion. ${ }^{25}$ Thus, the confessions obtained through these methods could not be deemed sufficiently voluntary to satisfy the requirements of the Constitution. ${ }^{26}$

In setting forth such a landmark rule, which was to prove in many ways both revolutionary and controversial, ${ }^{27}$ the Court looked to offer historical support for its conclusions. The Court's reference to the Star Chamber ${ }^{28}$ seems quite apt, both as a representation of the kind of coercion the Court was determined to prevent and as an illustration of the abuses that, as a historical matter, gave rise to the protections incorporated into the Fifth Amendment.

In contrast, the reference to-and at least partial reliance onthe rule of criminal confessions in Jewish law seems substantively, conceptually, and historically misplaced. Most basically, as the footnote in Miranda acknowledges, the Jewish legal system prescribes an

${ }^{24}$ See Miranda, 384 U.S. at 467-79.

${ }^{25}$ See id. at 448-56.

${ }^{26}$ See id. at $457-58$.

${ }^{27}$ In addition to the sharp concurring and dissenting opinions offered in response to the Miranda Court's majority opinion, see id. at 499 (Clark, J., concurring in part and dissenting in part); id. at 504 (Harlan, J., dissenting); id. at 536 (White, J., dissenting), the decision has prompted ongoing debate among both Supreme Court Justices, see, e.g., Dickerson v. United States, 530 U.S. 428 (2000), and scholars over both the Court's methodology and the outcome of the case. See, e.g., Evan H. Caminker, Miranda and Some Puzzles of "Prophylactic" Rules, 70 U. CIN. L. REv. 1 (2001); Gerald M. Caplan, Questioning Miranda, 38 VAND. L. ReV. 1417 (1985); Paul G. Cassell, All Benefits, No Costs: The Grand Illusion of Miranda's Defenders, 90 Nw. U. L. REV. 1084 (1996); Paul G. Cassell \& Richard Fowls, Handcuffing the Cops? A Thirty-Year Perspective on Miranda's Harmful Effects on Law Enforcement, 50 STAN. L. REV. 1055 (1998); Joseph D. Grano, Prophylactic Rules in Criminal Procedure: A Question of Article III Legitimacy, 80 Nw. U. L. REv. 100 (1985); Yale Kamisar, The Warren Court (Was It Really So Defense-Minded?), The Burger Court (Is It Really So Prosecution-Oriented?), and Police Investigatory Practices, in The Burger COURT: THE COUNTER-Revolution That WASN'T 62, 82 (Vincent Blasi ed., 1983); Stephen J. Schulhofer, Miranda's Practical Effect: Substantial Benefits and Vanishingly Small Social Costs, 90 NW. U. L. REv. 500 (1996); Stephen J. Schulhofer, Reconsidering Miranda, 54 U. CHI. L. REV. 435 (1987); David A. Strauss, The Ubiquity of Prophylactic Rules, 55 U. CHI. L. REV. 190 (1988); Symposium, Miranda After Dickerson: The Fulure of Confession Law, 99 MiCH. L. REv. 879 (2001).

${ }^{23}$ See Miranda v. Arizona, 384 U.S. 436, 458-59 (1966). 
absolute ban on the admissibility of a criminal defendant's selfincriminating statements. ${ }^{29}$ In stark contrast, pursuant to the rule established in Miranda, interrogation of criminal defendants remains among the most important and effective tools of law enforcement, and voluntary criminal confessions remain among the most valuable pieces of prosecutorial evidence. It seems anomalous to rely on a legal system with an outright ban on criminal confessions in support of a rule that fully accepts criminal confessions, as long as they are not the product of coercion.

As a conceptual matter, Miranda's reliance on Jewish law seems ill-suited for application in the American legal system. Notably, Maimonides offers possible rationales for the ban on criminal confessions in Jewish law, rooted in psychological and philosophical insights into the human condition. ${ }^{30}$ Strikingly, however, rather than applying these more accessible reasons for the rule, the Supreme Court quoted exclusively from Maimonides' conclusion that, ultimately, the ban on criminal confessions stands as a "divine decree." The theological expression of a rule in Jewish law, premised on divine authority, does not translate to the American legal system. ${ }^{32}$ The Miranda Court fails to offer an explanation as to why American law should accord even persuasive authority to a religious rule, and does not identify a rationale for the rule that would prove applicable in the context of the logic of the American legal system.

Finally, to the extent that the Court was merely referencing Jewish law as part of the historical establishment of "the privilege against

29 See id. at 458 n.27.

so See Laws Concerning the Sanhedrin and the Penalties Within Their Jurisdiction, supra note 18 , treatise 1 , ch. 18 , I 6 , at 53 .

[I] $\mathrm{t}$ is possible that [the confessor] was confused in mind when he made the confession. Perhaps he was one of those who are in misery, bitter in soul, who long for death, thrust the sword into their bellies or cast themselves down from the roofs. Perhaps this was the reason that prompted him to confess to a crime he had not committed, in order that he might be put to death.

Id. For more complete discussions of the psychological analysis provided by Maimonides and its potential application to the American legal system, see Norman Lamm, The 5th Amendment and Its Equivalent in Jewish Law, DECALOGUE J., 1, Jan.-Feb. 1967, at 1, 11-12; Levine, An Introduction to Self-Incrimination in Jewish Law, supra note 12, at 266-76.

31 See Miranda, 384 U.S. at 458 n.27 (quoting Laws Concerning the Sanhedrin and the Penalties Within Their Jurisdiction, supra note 18, ch. 18, If 6, at 53).

${ }^{32}$ To use an admittedly overstated analogy, we would not accept an argument that the United States should allow only kosher food because in the Jewish legal system, based on divine decree, only kosher food is permitted. 
self-incrimination," ${ }^{38}$ there is scant evidence of a direct historical connection between the rules against self-incrimination in the Jewish and American legal systems. ${ }^{34}$ Although some have attempted to trace the origins of the Fifth Amendment back to antecedents in Jewish law, ${ }^{35}$ the Court does not offer this argument, and in the view of most scholars, any such efforts remain tenuous at best. ${ }^{36}$

In short, Miranda's references to Jewish law are certainly significant-and, appropriately, rely on the work of scholars of Jewish lawbut the Court's attempt to apply these lessons from Jewish law to the American rule of criminal interrogation remains vulnerable to questions of relevance and methodology.

\section{GARRITY V. NEW JERSEY: AN ALTERNATIVE APPROACH FOR THE APPLICATION OF JEWISH LEGAL THEORY IN AMERICAN LAW}

At the same time, a critique of the analysis in Miranda need not preclude the application of insights and lessons from Jewish law and legal theory within the context of the American legal system. In fact, less than one year after Miranda, the Supreme Court issued another opinion that relied, in part, on the rule against self-incrimination in Jewish law as well as on a reprinted version of Rabbi Lamm's article. ${ }^{37}$ This time, however, the Court applied Jewish legal theory in a manner that is more satisfying and convincing.

In the 1967 case of Garrity v. New Jersey, the state conducted an investigation into alleged fixing of traffic tickets by police officers. ${ }^{38}$

33 Miranda, 384 U.S. at 458 (emphasis added).

34 See, e.g., Aaron Kirschenbaum, Self-Incrimination IN JeWish LaW 19-21 (1970); LEVY, supra note 12, at 439-40 (stating that "[w] hether the existence of the right against self-incrimination in Talmudic law in any way influenced the rise of the right in Anglo-American law is an intriguing question" but concluding that "the answer, if based on evidence rather than speculation, must be negative"); Arnold Enker, Self-Incrimination, in JEWISH LAW AND CURRENT LEGAL PROBLEMS, supra note 12, at 169,169 ("The thesis of my presentation today will be that exaggerated claims have been and are being made for the sources of self-incrimination in Jewish law, and for the notion that important lessons can be learned from Jewish [1] aw with respect to self-incrimination.").

${ }^{35}$ See Braz, supra note 12, at 162 (arguing that "Jewish law and Talmudic jurisprudence constitute one of the main streams that converged to form the unique common law doctrine against self-incrimination"); Horowitz, supra note 12, at 125-27 (indicating that the source of the principle against self-incrimination lies in Talmudic law).

${ }^{36}$ See sources cited supra note 34.

37 See Lamm, supra note 30, at 1.

38385 U.S. 493, 494 (1967). 
Prior to being questioned, the officers were told that they had the right to refuse to answer questions on the grounds that the response would incriminate them, but that refusal to answer would subject them to removal from office. ${ }^{39}$ The Supreme Court focused on the issue of whether the responses to these questions were admissible as voluntary confessions. ${ }^{40}$

Writing for the majority, Justice Douglas posed the issue in clear and stark terms, stating that " $[\mathrm{t}]$ he choice imposed on petitioners was one between self-incrimination or job forfeiture." ${ }^{41}$ Relying on prior decisions, the Court emphasized that " $[\mathrm{c}]$ oercion that vitiates a confession... can be mental as well as physical," and "[s]ubtle pressures may be as telling as coarse and vulgar ones." viewed the relevant question as "whether the accused was deprived of his 'free choice to admit, to deny, or to refuse to answer,", found that " $[t]$ he option to lose their means of livelihood or to pay the penalty of self-incrimination is the antithesis of free choice to speak out or to remain silent." ${ }^{45}$. Therefore, the Court concluded, "the statements were infected by the coercion inherent in this scheme of questions and cannot be sustained as voluntary under our prior decisions." ${ }^{46}$

As in Miranda, the majority opinion in Garrity includes a footnote referencing Jewish law in support of the Court's conclusion. ${ }^{47}$ When compared with the footnote in Miranda, however, the discussion of Jewish law in Garrity is more complete, more conceptual, in some ways more modest in its potential application to the American legal system, and, accordingly, more convincing and effective.

The footnote in Garrity, which consists entirely of an extensive quotation from sections of Rabbi Lamm's article, opens with the ac-

39 Id.

Id $I$. at 496.

${ }^{4}$ Id.

42 Id. (quoting Blackburn v. Alabama, 361 U.S. 199, 206 (1960) (quotation marks omitted)).

${ }^{43} I d$. at 496 (citing Haynes v. Washington, 373 U.S. 503 (1963); Leyra v. Denno, 347 U.S. 556 (1954)).

" Garrity, 385 U.S. at 496 (quoting Lisenba v. California, 314 U.S. 219, 241 (1941)).

45 Id.

${ }^{46}$ Id. at $497-98$.

17 Id. at 497 n.5. 
knowledgment that Jewish law and American law differ substantively-and substantially-with respect to rules of self-incrimination:

It should be pointed out, at the very outset, that the Halakhah does not distinguish between voluntary and forced confessions .... And it is here that one of the basic differences between Constitutional and Talmudic Law arises. According to the Constitution, a man cannot be compelled to testify against himself.... The Halakhah ... does not permit self-incriminating testimony. It is inadmissible, even if voluntarily offered. Confession ... is simply not an instrument of the Law. The issue [in Jewish law], then, is not compulsion, but the whole idea of legal confession.

In light of these basic distinctions in both the scope and the apparent concerns behind the limitations on confessions in Jewish law and American law, it seems surprising that the Garrity Court would derive any lessons from the absolute ban on criminal confessions in the Jewish legal system. If anything, Jewish legal theory, which bans confessions without any consideration of voluntariness, appears completely irrelevant to the Court's analysis in Garrity, which turned entirely on the issue of coercion. ${ }^{49}$

The Court's reasoning becomes apparent from the remaining two paragraphs of the footnote. Moving from the substance and scope of the rule against self-incrimination in Jewish law, the Court quotes Rabbi Lamm's analysis of possible rationales underlying the rule. Building on Maimonides' insights into human psychology, Rabbi Lamm explains that, although the rule is a divine decree, "The Halakhah ... is . . . concerned with protecting the confessant from his own aberrations which manifest themselves, either as completely fabricated confessions, or as exaggerations of the real facts. "50 Drawing on modern psychoanalytic theory, Rabbi Lamm adds that "[w] hile certainly not all, or even most criminal confessions are directly attributable, in whole or in part, to the Death Instinct, the Halakhah is sufficiently concerned with the minority of instances, where such is the case, to disqualify all criminal confessions and to discard confession as a legal instrument."

Finally, the Court quotes Rabbi Lamm's conclusion:

48 Id. (quoting Lamm, supra note 30, at 10) (emphasis added).

49 See id., 385 U.S. at $496-98$.

50 Garrity, 385 U.S. at 497 n.5 (emphasis added) (quoting Lamm, supra note 30, at $12)$.

Id. at 497-98 n.5 (quoting Lamm, supra note 30 , at 12). 
[T] he Constitutional ruling on self-incrimination concerns only forced confessions, and its restricted character is a result of its historical evolution as a civilized protest against the use of torture in extorting confessions. The Halakhic ruling, however, is much broader and discards confessions in toto, and this because of its psychological insight and its concern for saving man from his own destructive inclinations.

Although the Court does not offer any comments on Rabbi Lamm's remarks, the implications derived from Jewish law are quite clear, adding considerable depth to the Court's analysis. The Court was not addressing the general question of whether the Constitution-or Jewish law-permits the use of self-incrimination to obtain evidence in a criminal case; as the Court observes, the Constitution admits voluntary confessions and Jewish law does not. This substantive distinction, however, was not pertinent to the issue in Garrity.

Instead, in an effort to analyze the voluntariness of the police officers' statements, the Garrity Court engaged in a complex consideration of various forms of coercion, both blatant and subtle. The footnote referencing Jewish law is offered in support of the Court's assertion that "the statements were infected by the coercion inherent in this scheme of questioning and cannot be sustained as voluntary...." In fact, the footnote signal is placed in the middle of the sentence, modifying the word "coercion."

Accordingly, the Court's decision turned on the recognition that, for the purposes of assessing the voluntariness of a statement, courts must consider both physical and more subtle-but no less real-forms of psychological coercion. ${ }^{55}$ This recognition is precisely the insight that Rabbi Lamm, more than ten years earlier, ${ }^{56}$ and Maimonides, more than 700 years earlier, ${ }^{57}$ had derived from the ban on self-incrimination in Jewish law. The Court in Garrity applied the conceptual lesson from Jewish law to support its conclusion that American law should likewise take into account more complex and subtle forms of coercion, such as the threat of losing a job, that can

32 Id. (quoting Lamm, supra note 30 , at 12).

53 Id. at $497-98$ \& n.5.

54 See id.

${ }_{55}$ Id. at 497-99.

56 See Lamm, supra note 30.

57 See Laws Concerning the Sanhedrin and the Penalties Within Their Jurisdiction, supra note 18. 
impose sufficient psychological pressure as to render involuntaryand therefore inadmissible-any ensuing confessions. ${ }^{58}$

Thus, the methodology in Garrity provides a model preferable to the approach in Miranda on a number of grounds. Garrity more clearly emphasizes the distinction between the rules of selfincrimination in Jewish law and American law, remaining faithful to each legal system on its own terms. Therefore, Garrity makes no attempt at an unlikely substantive or historical reconciliation between the two rules. Instead, Garrity draws a conceptual lesson from Jewish law in a way that accurately conveys the logic of the Jewish legal system and then applies the lesson to American law in a way that makes sense within the logic of the American legal system. As a result, the lessons derived from Jewish legal theory contribute depth to the Court's understanding, interpretation, and determination of American law and legal theory.

\section{APPLICATIONS OF JEWISH LEGAL THEORY IN AMERICAN LEGAL SCHOLARSHIP}

To be sure, this discussion is not intended to imply a strict dichotomy between substantive and conceptual applications of Jewish law in the American legal system, or to suggest that the reference to Jewish law in Miranda is without value. Instead, the contrast between Mirand $a$ and Garrity illustrates the broader methodological point, that effective application of a principle in Jewish law entails the ability to identify, independent of theological justifications, an underlying rationale for the principle that can be evaluated within the internal logic of the American legal system. Indeed, this methodology has been widely employed in American legal scholarship, resulting in a substantial body of literature dedicated to the application of Jewish legal theory to American legal theory.

Much of this literature has examined substantive areas of law, including, among others, criminal law and procedure, ${ }^{59}$ capital pu-

58 Garrity, 385 U.S. at 497-99.

59 See, e.g., 1 EMANuel. B. Quint \& NeIL S. HeCHT, JEWISH JuRISPRUdENCE: ITS SOURCES AND MODERN APPLICATIONS 34-37, 44-51, 154-72 (1980); 2 EMANUEL B. QUINT \& NEIL S. HECHT, JEWISH JURISPRUDENCE: ITS SOURCES AND MODERN APPLICATIONS 2-8 (1986); J. David Bleich, Jewish Law and the State's Authority to Punish Crime, 12 CARDozo L. Rev. 829 (1991); Moshe A. Bleich \& Daniel Pollack, Search and Seizure in Schools: A Comparison of Historical Jewish Legal Sources and Contemporary United States Law, 7 IND. INT'L \& COMP. L. REV. 379 (1997); Arnold N. Enker, Aspects of Interaction Between the Torah Law, The King's Law, and the Noahide Law in Jewish Criminal Law, 12 CARDOZO L. REV. 1137 (1991); Arnold N. Enker, Error Juris in Jewish Criminal 
nishment, ${ }^{60}$ torts, ${ }^{61}$ property, ${ }^{62}$ tax, ${ }^{63}$ and commercial law. ${ }^{64}$ Drawing upon thousands of years of Jewish legal scholarship, this work relies

Law, 11 J.L. \& RELIGION 23 (1994); Clifford S. Fishman, The Mirror of Justice Lecture: "Old Testament Justice," 51 CATH. U. L. REV. 405 (2002); Aaron Kirschenbaum, M'kohmah shel Ha'ohnishah B'mishpat Ha'ivi Ha'plili Perek B'hashkafah Ha'pinologist shel Chazal v'shel Harishohnim [The Role of Punishment in Jewish Criminal Law: A Chapter in Rabbinic Penological Thought], 12 TeL AvTV U. L. Rev. 253 (1987), translated in 9 JEWISH L. ANN. 123 (1991); Levine, An Introduction to Self-Incrimination in Jewish Law, supra note 12; Levine, Miranda, Dickerson, and Jewish Legal Theory, supra note 12; Beth C. Miller, A Comparison of American and Jewish Legal Views on Rape, 5 COLUM. J. GENDER \& L. 182 (1996); Martin H. Pritikin, Punishment, Prisons, and the Bible: Does "Old Testament Justice" Justify Our Retributive Culture?, 28 CARDOZO L. REv. 715 (2006); Irene Merker Rosenberg \&c Yale L. Rosenberg, Advice From Hillel and Shammai on How to Read Cases: Of Specificity, Retroactivity and New Rules, 42 AM. J. CoMP. L. 581 (1994); Irene M. Rosenberg \& Yale L. Rosenberg, "Cain Rose up Against His Brother Abel and Killed Him": Murder or Manslaughter?, 30 GA. J. INT'L \& COMP. L. 37 (2001); Irene Merker Rosenberg \& Yale L. Rosenberg, Guilt: Henry Friendly Meets the MaHaRaL of Prague, 90 MiCH. L. REV. 604 (1991); Rosenberg \& Rosenberg, supra note 12; Irene Merker Rosenberg et al., Murder by Gruma: Causation in Homicide Cases Under Jewish Law, 80 B.U. L. REV. 1017 (2000); Irene Merker Rosenberg \& Yale L. Rosenberg, "Perhaps What Ye Say Is Based Only on Conjecture": Circumstantial Evidence, Then and Now, 31 Hous. L. REv. 1371 (1995); Irene Merker Rosenberg et al., Return of the Stubborm and Rebellious Son: An Independent Sequel on the Prediction of Future Criminality, 37 BRANDEIS L.J. 511 (1999); Aaron M. Schreiber, The Jurisprudence of Dealing with Unsatisfactory Fundamental Law: A Comparative Glance at the Different Approaches in Medieval Criminal Law, Jewish Law and the United States Supreme Court, 11 PACE L. REV. 535 (1991).

6o See, e.g., 1 QuINT \& HeCHT, supra note 59, at 15-18, 34-37, 154-72; Chad Baruch, 2000 McElroy Lectures: In the Name of the Father: A Critique of Reliance upon Jewish Law to Support Capital Punishment in the United States, 78 U. DET. MERCY L. REV. 41 (2002); Gerald J. Blidstein, Capital Punishment-The Classic Jewish Discussion, 14 JudaISM 159 (1965); Steven Davidoff, A Comparative Study of the Jewish and the United States Constitutional Law of Capital Punishment, 3 ILSA J. INT'L \& COMP. L. 93 (1996); Bruce S. Ledewitz \& Scott Staples, Reflections on the Talmudic and American Death Penalty, 6 U. Fla. J.L. \& Pub. Pol'y 33 (1993); Samuel J. Levine, Capital Punishment and Religious Arguments: An Intermediate Approach, 9 WM. \& MARY BILL RTS. J. 179 (2000); Samuel J. Levine, Capital Punishment in Jewish Law and its Application to the American Legal System: A Conceptual Overview, 29 ST. MARY's L.J. 1037 (1998); Samuel J. Levine, Playing God: An Essay on Law, Philosophy, and American Capital Punishment, 31 N.M. L. REv. 277 (2001); Irene Merker Rosenberg \& Yale L. Rosenberg, Lone Star Liberal Musings on "Eye for Eye" and the Death Penalty, 1998 UTAH L. REv. 505; Irene Merker Rosenberg \& Yale L. Rosenberg, Of God's Mercy and the Four Biblical Methods of Capital Punishment: Stoning, Burning, Beheading, and Strangulation, 78 TUL. L. REV. 1169 (2004); Daniel A. Rudolph, Note, The Misguided Reliance in American Jurisprudence on Jewish Law to Support the Moral Legitimacy of Capital Punishment, 33 AM. CRIM. L. REV. 437 (1996).

${ }^{61}$ See, e.g., 1 QUINT \& HECHT, supra note 59, at 41-49, 86-122, 126-38, 206-13; 2 QUINT \& HECHT, supra note 59, at 2-8, 91-144; Steven F. Friedell, Medical Malpractice in Jewish Law: Some Parallels to External Norms and Practices, 6 CHI.-KENT J. INT'L \& ComP. L. 1 (2006); Steven F. Friedell, Nobody's Perfect: Proximate Cause in American and Jewish Law, 25 Hastings INT'L \& COMP. L. REv. 111 (2002); Sheldon Nahmod, The Duty to Rescue and the Exodus Meta-narrative of Jewish Law, 16 ARIZ. J. INT'L \& COMP. L. 751 
on sometimes surprising insights from the Jewish legal system to provide fresh ways of looking at American law.

For example, in considering the perennially perplexing issue of capital punishment, American legal scholars have examined the Talmud and other sources of Jewish law only to find a diversity of approaches, including a debate between abolitionists at one end of the spectrum and those advocating the deterrent value of capital punishment at the other end, with still others taking intermediate positions. $^{65}$ These debates offer valuable conceptual discussions from a legal system that has addressed for millennia some of the same arguments that arise in contemporary American legal discourse.

Other scholarship applies substantive Jewish law to emerging and cutting-edge issues in American law. Because Jewish law relates to all areas of life and all realms of human activity, ${ }^{66}$ it must address questions that arise as a result of technological advances in areas such

(1999); Elie Mischel, Note, "Thou Shalt Not Go About as a Talebearer Among Thy People": Jewish Law and the Private Facts Tort, 24 CARDOZO ARTS \& ENT. L.J. 811 (2006); Shaya Rochester, Note, What Would Have Seinfeld Done Had He Lived in a Jewish State? Comparing the Halakhic and Statutory Duties to Aid, 70 WASH. U. L.Q. 1185 (2001).

62 See, e.g., 1 QUINT \& HECHT, supra note 59, at 41-45, 64-70, 86-88, 94-98, 10408, 110-19, 126-32; 2 QUINT \& HECHT, supra note 59, at 115-32; Michael J. Broyde \&c Michael Hecht, The Return of Lost Property According to a Jewish E Common Law: A Comparison, 12 J.L. \& RELIGION 225 (1995); Joshua A. Klarfeld, Note, Chazakah: Judaic Law's Non-Adverse Possession, 52 CLEV. ST. L. REV. 623 (2004-2005); Ora R. Sheinson, Note, Lessons from the Jewish Law of Property Rights for the Modern American Takings Debate, 26 COLUM.J. ENVTL. L. 483 (2001).

${ }^{63}$ See, e.g., 2 QUINT \& HECHT, supra note 59, at 137-40; Adam S. Chodorow, Agricultural Tithing and (Flat) Tax Complexity, 68 U. PITT. L. REv. 267 (2006); Adam S. Chodorow, Biblical Tax Systems and the Case for Progressive Taxation, 23 J.L. \& RELIGION 51 (2007-2008); Adam S. Chodorow, Maaser Kesafim and the Development of Tax Law, 8 FLA. TAX. REV. 153 (2007).

G See, e.g., 1 QUINT \& HECHT, supra note 59, at 39-41, 84-86; 2 QUINT \& HECHT, supra note 59, at 8-32, 135-37; Dennis W. Carlton \& Avi Weiss, The Economics of Religion, Jewish Survival, and Jewish Attitudes Toward Competition in Torah Education, $30 \mathrm{~J}$. LEGAL STUD. 253 (2001); Aaron Levine, Aspects of the Lemons Problem as Treated in Jewish Law, 23 J.L. \& RELIGION 379 (2008); Shahar Lifshitz, Oppressive-Exploitative Contracts: A Jewish Law Perspective, 23 J.L. \& REL.JGION 425 (2008); James Scheinman, Jewish Business Ethics, 1 U.C. DAVIS J. INT'L L. \& POL'Y 63 (1995); Keith Sharfman, The Law and Economics of Hoarding, 19 LOY. CONSUMER L. REV. 179 (2007); Shayna M. Sigman, Kosher Without Law: The Role of Nonlegal Sanctions in Overcoming Fraud Within the Kosher Food Industry, 31 FLA. ST. U. L. REV. 509 (2004); Leon Wildes, A Modern Restatement of Jewish Civil Law, 18 CARDOZO L. REV. 2037, 2038 (1997) (book review).

${ }^{65}$ See, e.g., TALMUd BAVLI: TRACTATE MAKKOS $7 \mathrm{a}^{1}$.

${ }_{66}$ See supra note 8 and accompanying text. 
as bioethics ${ }^{67}$ and intellectual property. ${ }^{68}$ Indeed, over thousands of years, the Jewish legal system has been continuously confronted with the ongoing challenge of applying the law to newly emerging realities. $^{69}$ Thus, the Jewish legal model and Jewish legal history provide not only substantive responses to specific questions, but also a conceptual framework for the broader and more universal issue of adapting a legal system to inevitable advances in science and technology.

${ }^{67}$ See, e.g., FELDMAN, supra note 7, at 251-94; Darrel W. Amundsen, The Ninth Circuit Court's Treatment of the History of Suicide by Ancient Jews and Christians in Compassion in Dying v. State of Washington: Historical Naiveté or Special Pleading?, 13 Issurs L. \& MED. 365 (1998); J. David Bleich, Abortion in Halakhic Literature, in JEWISH BIOETHICS 155 (Fred Rosner \& J. David Bleich eds., augmented ed. 2000); Michael Broyde, Cloning People: A Jewish Analysis of the Issues, 30 CONN. L. REV. 503 (1998); Michael Broyde, Genetically Engineering People: A Jewish Law Analysis of Personhood, 13 ST. THOMAS L. REV. 877 (2001); Elliot N. Dorff, Human Cloning: A Jewish Perspective, 8 S. CAL. INTERDISC. L.J. 117 (1998); Immanuel Jakobovits, Jewish Views on Abortion, in JEWISH BIOETHICS, supra, at 139; Daniel Pollack et al., Anderson v. St. Francis-St. George Hospital: Wrongful Living from an American and Jewish Legal Perspective, 45 CLEV. ST. L. REv. 621 (1997); Chaim Povarsky, Regulating Advanced Reproductive Technologies: A Comparative Analysis of Jewish and American Law, 29 U. TOL. L. REv. 409 (1998); Steven H. Resnicoff, Jewish Law Perspectives on Suicide and Physician-Assisted Dying, 13 J.L. \& Religion 289 (1999); Steven H. Resnicoff, Physician Assisted Suicide Under Jewish Law, 1 DEPAUL J. HEAlth CARE L. 589 (1997); Steven H. Resnicoff, Supplying Human Body Parts: A Jewish Perspective, 55 DePaul L. Rev. 851 (2006); Daniel B. Sinclair, Assisted Reproduction in Jewish Law, 30 FordhAM URB. L.J. 71 (2002); Daniel Sinclair, The Obligation to Heal and Patient Autonomy in Jewish Law, 13 J.L. \& RELIGION 351 (1999); Alan Mayor Sokobin, Shaken Baby Syndrome: A Comparative Study: Anglo-American Law and Jewish LawLegal, Moral, and Ethical Issues, 29 U. TOL. L. REV. 513 (1998); Marc D. Stern, "And You Shall Choose Life": Futility and the Religious Duty to Preserve Life, 25 SETON HALl L. REV. 997 (1995); Miryam Z. Wahrman, Fruit of the Womb: Artificial Reproductive Technologies E' Jewish Law, 9 J. GENDER RACE \& JUST. 109 (2005); Stephen J. Werber, Ancient Answers to Modern Questions: Death, Dying, and Organ Transplants-A Jewish Law Perspective, 11 J.L. \& HEALTH 13 (1996).

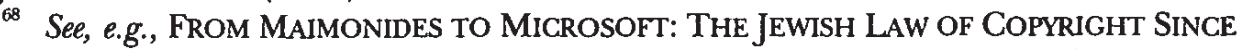
THE BIRTH OF PRINT (Neil W. Netanel \& David Nimmer eds., forthcoming 2010); Jack Achiezer Guggenheim, KOA is A.O.K.: The Second Circuit's Recent Kosher Trademark Decision Further Illustrates that the Patent and Trademark Office Must Answer to a Higher Authority, 22 COLUM. J.L. \& ARTS 203 (1998); Matthew I. Kozinets, Copyright and Jewish Law: The Dilemma of Change, 1 U.C. DAVIS J. INT'L L. \& POL'Y 83 (1995); Roberta Rosenthal Kwall, Inspiration and Innovation: The Intrinsic Dimension of the Artistic Soul, 81 NOtRe DAME L. REV. 1945 (2006); David Nimmer, Adams and Bits: Of Jewish Kings and Copyrights, 71 S. CAL. L. REv. 219 (1998).

${ }_{69}$ See, e.g., ARYEH KAPLAN, The ARYEH KAPLAN REAdER, supra note 7, at 83-88; AdIN Steinsaltz, The Essential TALMud 234-38 (Chaya Galai trans., 1976); Michael Broyde \& Howard Jachter, The Use of Electricity on Shabbat and Yom Tov, $21 \mathrm{~J}$. HALACHA \& CONTEMP. SOC'Y 4 (1991); Howard Jachter \& Michael Broyde, Electrically Produced Fire or Light in Positive Commandments, $25 \mathrm{~J}$. HALACHA \& CONTEMP. SOC'Y 89 (1993); Levine, Jewish Legal Theory and American Constitutional Theory, supra note 5, at 456-57; Arthur Schaffer, The History of Horseradish as the Bitter Herb on Passover, 8 GESHER 217 (1981). 
Not surprisingly, Jewish legal theory has also played a central role in emerging areas of American legal scholarship that relate directly to issues of religion. As one particularly poignant example, the last decade has experienced the growth of the religious lawyering movement, comprised of lawyers and scholars exploring the relationship between religion and the practice of law. ${ }^{70}$ The movement has succeeded as an intellectual force within the legal academy in part due to contributions reflecting a variety of religious perspectives, including insights from Jewish legal theory that address substantive areas of American legal practice, such as criminal advocacy and corporate counseling, as well as conceptual approaches to the roles of the lawyer within the American adversary system. ${ }^{71}$ Notably, some of

${ }^{70}$ See, e.g., Thomas E. Baker \& Timothy W. Floyd, A Symposium Précis, 27 TEX. TECH L. REV. 911, 911 (1996) (including essays "in the nature of personal narratives" that detail how the author "reconciled [his/her] professional life with [his/her] faith life"); Colloquium, Can the Ordinary Practice of Law Be a Religious Calling?, 32 PEPP. L. REV. 373 (2005); Marie A. Failinger, Editor's Preface to the AALS Section on Professional Responsibility 2006 Annual Meeting Papers, 21 J.L. \& RELIGION 265, 265 (2006); Rose Kent, What's Faith Got to Do With It?, FoRDHAM LAW., Summer 2001, at 10 (on file with author); Howard Lesnick, Riding the Second Wave of the Sa-Called Religious Lawyering Movement, 75 ST. JoHN's L. REv. 283 (2001); Russell G. Pearce \& Amelia J. Uelmen, Religious Lawyering in a Liberal Democracy: A Challenge and an Invitation, 55 CASE W. RES. L. REV. 127 (2004); Symposium on Law E Politics as Vocation, 20 NOTRE DAME J.L. ETHICS \& PUB. POL'Y 1 (2006) (discussing the Jewish perspective of American legal practice and how being an attorney might be a divine calling); Symposium on Lawyering and Personal Values, 38 CATH. LAW. 145, 149 (1998) (focusing on the personal, religious, and other ethical values of lawyers in the legal profession); Symposium, $R e-$ discovering the Role of Religion in the Lives of Lawyers and Those They Represent, 26 FORDHAM URB. L.J. 821 (1999); Symposium, The Relevance of Religion to a Lawyer's Work: An Interfaith Conference, 66 FORDHAM L. REV. 1075 (1998); Robert K. Vischer, Heretics in the Temple of Law: The Promise and Peril of the Religious Lawyering Movement, 19 J.L. \& RELIGION 427 (2004); Gerry Whyte, Integrating Professional Practice and Religious Faith: The Religious Lawyering Movement, DocrRINE \& LIFE, May-June 2005, at 18.

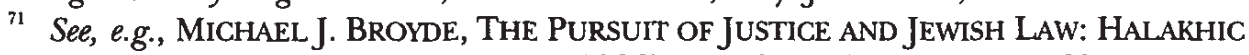
Perspectives On THE Legal Profession (1996); Mordecai Biser, Can an Observant Jew Practice Law?: A Look at Some Halakhic Problems, 11 JEWISH L. ANN. 101 (1994); Michael J. Broyde, Practicing Criminal Law: A Jewish Analysis of Being a Prosecutor or Defense Attorney, 66 FORDHAM L. REv. 1141 (1998); Monroe H. Freedman, Legal Ethics from a Jewish Perspective, 27 TEX. TECH L. REv. 1131 (1996); Dov I. Frimer, The Role of a Lawyer in Jewish Law, 1 J.L. \& RELIGION 297 (1983); Jerome Hornblass, The Jewish Lawyer, 14 CARDOZO L. REV. 1639 (1993); Levine, supra note 8; Samuel J. Levine, Further Reflections on the Role of Religion in Lawyering and in Life, 11 REGENT U. L. REV. 31 (1999); Samuel J. Levine, Introductory Note: Symposium on Lauyering and Personal ValuesResponding to the Problems of Ethical Schizophrenia, 38 CATH. LAW. 145 (1998); Samuel J. Levine, $A$ Look at American Legal Practice Through a Perspective of Jewish Law, Ethics, and Tradition: A Conceptual Overview, 20 NOTRE DAME J.L. ETHICs \& PUB. POL'Y 11 (2006); Samuel J. Levine, Professionalism Without Parochialism: Julius Henry Cohen, Rabbi Nachman of Breslor, and the Stories of Two Sons, 71 FORDHAM L. REv. 1339 (2003); Samuel J. 
the most significant lessons are derived though careful analysis of Jewish law on its own terms, including exploration of ways in which the Jewish legal system differs, at times dramatically, from the American legal system. Serving as a contrast case, the Jewish legal model enables American legal scholars to see the American legal system and American legal practice in a new light.

\section{CONCLUSION}

Along with the analysis of contributions from Jewish legal theory to the study of various substantive areas of American law, it may be fitting to close this Essay on a more conceptual level, noting some of the insights Jewish legal theory continues to provide in more theoretical areas of American law, such as jurisprudence, ${ }^{72}$ legal interpreta-

Levine, Taking Ethical Obligations Seriously: A Look at American Codes of Professional Responsibility Through a Perspective of Jewish Law and Ethics, 57 CATH. U. L. REV. 165 (2007); Samuel J. Levine, Taking Ethics Codes Seriously: Broad Ethics Provisions and Unenumerated Ethical Obligations in a Comparative Hermeneutic Framework, 77 TUL. L. REV. 527 (2003); Samuel J. Levine, The Yale L. Rosenberg Memorial Lecture: Taking Prosecutorial Ethics Seriously: A Consideration of the Prosecutor's Ethical Obligation to "Seek Justice" in a Comparative Analytical Framework, 41 Hous. L. REv. 1337 (2004); Sanford Levinson, Identifying the Jewish Lawyer: Reflections on the Construction of Professional Identity, 14 CARDOZO L. REV. 1577 (1993); Russell G. Pearce, Jewish Lawyering in a Multicultural Society: A Midrash on Levinson, 14 CARdozo L. Rev. 1613 (1993); Russell G. Pearce, The Jewish Lawyer's Question, 27 TEx. TECH L. REV. 1259 (1996); Russell G. Pearce, Reflections on the American Jewish Lauyer, 17 J.L. \& RELIGION 179 (2002); Pearce \& Uelmen, supra note 70; Russell G. Pearce, To Save a Life: Why a Rabbi and a Jewish Lauyer Must Disclose a Client Confidence, 29 LoY. L.A. L. REV. 1771 (1996); Amy Porter, Representing the Reprehensible and Identity Conflicts in Legal Representation, 14 TEMP. POL. \& CIV. RTS. L. REV. 143 (2004); Nancy B. Rapoport, Living "Top-Down" in a "BottomUp" World: Musings on the Relationship Between Jewish Ethics and Legal Ethics, 78 NEB. L. REV. 18 (1999); Steven H. Resnicoff, The Attomey-Client Relationship: A Jewish Law Perspective, 14 Notre Dame J.L. ETHICS \& PUb. POL'y 349 (2000); Steven H. Resnicoff, A Jewish Look at Lauyering Ethics: A Preliminary Essay, 15 TOURO L. REv. 73 (1998); Steven H. Resnicoff, Lying and Lawyering: Contrasting American and Jewish Law, 77 NOTRE DAME L. Rev. 937 (2002); Arthur Gross Schaefer \& Peter S. Levi, Resolving the Conflict Between the Ethical Values of Confidentiality and Saving a Life: A Jewish View, 29 LOY. L.A. L. REV. 1761 (1996); Daniel B. Sinclair, Advocacy and Compassion in the Jewish Tradition, 31 Fordham URB. L.J. 99 (2003); Abbe Smith \& William Montross, The Calling of Criminal Defense, 50 MERCER L. Rev. 443 (1999); Marc D. Stern, The Attorney as Advocate and Adherent: Conflicting Obligations of Zealousness, 27 TEX. TECH L. REv. 1363 (1996); Israel Greisman, Note, The Jewish Criminal Lawyer's Dilemma, 29 FORDHAM URB. L.J. 2419 (2002).

${ }^{72}$ See, e.g., Yitzchok Adlerstein, Lawyers, Faith, and Peacemaking: Jewish Perspectives on Peace, 7 PEPP. DISP. ResOL. L.J. 177 (2007); J. David Bleich, Was Spinoza a Jewish Philosopher?, 25 CARDOZO L. ReV. 571 (2003); Michael J. Broyde, A Jewish Law View of the World, 54 EMORY L.J. 79 (2005); Robert A. Baruch Bush, Mediation and ADR: Insights from the Jewish Tradition, 28 ForDHAM URB. L.J. 1007 (2001); David C. Flatto, The Historical Origins of Judicial Independence and Their Modern Resonances, 117 YALE L.J. POCKET 
tion, $^{73}$ and legal narrative. ${ }^{74}$ Indeed, the current turn to Jewish legal theory in American legal scholarship may be attributed in large part to the contributions of Robert Cover, ${ }^{75}$ whose groundbreaking work,

PART 8 (2007), http://www.yalelawjournal.org/the-yale-law-journal-pocket-part/ constitutional-law/the-historical-origins-of-judicial-independence-and-their-modernresonances/; Aaron Kirschenbaum, Modern Times, Ancient Laws-Can the Torah Be Amended? Equity as a Source of Legal Development, 39 ST. LouIS U. L.J. 1219 (1995); Norman Lamm \& Aaron Kirschenbaum, Freedom and Constraint in the Jewish Judicial Process, 1 CARDOZO L. Rev. 99 (1979); Samuel J. Levine, Richard Posner Meets Reb Chaim of Brisk: A Comparative Study in the Founding of Intellectual Legal Movements, 8 SAN DIEGO INT'L L.J. 95 (2006); Donna Litman, Jewish Law: Deciphering the Code by Global Process and Analogy, 82 U. DET. MERCY L. REV. 563 (2005); Timothy D. Lytton, "Shall Not the Judge of the Earth Deal Justly?": Accountability, Compassion, and Judicial Authority in the Biblical Story of Sodom and Gomorrah, 18 J.L. \& RELIGION 31 (2002); Chaim Saiman, Legal Theology: The Turn to Conceptualism in Nineteenth-Century Jewish Law, 21 J.L. \& RELIGION 39 (2005).

${ }^{73}$ See, e.g., Burton Caine, "The Liberal Agenda": Biblical Values and the First Amendment, 14 TOURO L. REv. 129 (1997); Kent Greenawalt, The Implications of Protestant Christianity for Legal Interpretation, 23 J.L. \& RELIGION 131 (2007); Samuel J. Levine, $A n$ Introduction to Legislation in Jewish Law, with References to the American Legal System, 29 Seton Hall L. Rev. 916 (1999); Samuel J. Levine, Unenumerated Constitutional Rights and Unenumerated Biblical Obligations: A Preliminary Study in Comparative Hermeneutics, 15 Const. Comment. 511 (1998); Michael Rosensweig, Eilu ve-Eilu Divrei Elokim Hayyim: Halakhic Pluralism and Theories of Controversy, in RABBINIC AUTHORIY AND PERSONAl. Autonomy 93 (Moshe Sokol ed., 1992); Jeffrey I. Roth, The Justification for Controversy Under Jewish Law, 76 CAL. L. REv. 337 (1988); Chaim Saiman, Jesus' Legal Theory-A Rabbinic Reading, 23 J.L. \& RELIGION 97 (2007); Maimon Schwarzschild, Pluralist Interpretation: From Religion to the First Amendment, 7 J. CONTEMP. LEGAL ISSUES 447 (1996); David A. Skeel, Jr., What Were Jesus and the Pharisees Talking About When They Talked Aboul Law?, 23 J.L. \& REligion 141 (2007); Symposium, Text, Tradition, and Reason in Comparative Perspective, 28 CARDOzO L. REV. 1 (2006); Emil A. Kleinhaus, Note, History as Precedent: The Post-Originalist Problem in Constitutional Law, 110 YALE L.J. 121 (2000); Note, Looking to Statutory Intertext: Toward the Use of the Rabbinic Biblical Interpretive Stance in American Statutory Interpretation, 115 HARV. L. REV. 1456 (2002).

${ }_{74}$ See, e.g., George Dargo, Deriving Law from the Biblical Narrative: The Book of Ruth, 40 New EnG. L. Rev. 351 (2006); Itzhak Englard, Majority Decision vs. Individual Truth: The Interpretations of the "Oven of Achnai " Aggadah, TRADITION, Spring-Summer 1975, at 137; Daniel J.H. Greenwood, Akhnai, 1997 UTAH L. REv. 309; Samuel J. Levine, Halacha and Aggada: Translating Robert Cover's Nomos and Narrative, 1998 UTAH L. REV. 465; Jennifer Nadler, Mar Ukba in the Fiery Furmace, 19 L. \& LiTERATURE 1 (2007); Suzanne Last Stone, Justice, Mercy, and Gender in Rabbinic Thought, 8 CARDozo STUD. L. \& LITERATURE 139 (1996); Symposium, Rethinking Robert Cover's Nomos and Narrative, 17 YALE J.L. \& HUMAN. 1 (2005).

75 See Stone, supra note 5, at 819-20.

[T] he publication of Cover's work was a significant turning point in the growth of this new literature in American law and Judaism. . . . Robert Cover made it respectable to draw on the Jewish tradition in public discourse. Many of the articles citing Jewish sources in the past decade are either direct responses to Cover's work, whether critical or admiring, or attempts to carry forward Cover's intellectual project. Fi- 
particularly near the end of his life, explored a number of areas of American jurisprudence through a prism of Jewish law and legal theory.

Though Cover's scholarship stands out in many respects, his reliance on Jewish law is notable, in part, for the attempt to explore Jewish law on its own terms. Indeed, Cover often included his own translations of primary and secondary sources of Jewish law that were unfamiliar to most scholars of American law. ${ }^{77}$ As Cover acknowledged, at times these sources highlighted stark differences between the American legal system and the Jewish legal system, in both substance and underlying assumptions. ${ }^{78}$ Nevertheless, Cover was able to identify, within Jewish legal theory, theoretical lessons and conceptual insights that add to our understanding of American law and legal thought. Likewise, consistent with the methodology suggested in this Essay, scholars continue to look to sources of Jewish law on its own terms as a model for the application of Jewish legal theory to American law and legal scholarship.

nally, Robert Cover's work cuts across many of the important debates in contemporary American jurisprudence.

Id.; see also Bernard J. Hibbits, Making Sense of Metaphors: Visuality, Aurality, and the Reconfiguration of American Legal Discourse, 16 CARDOZO L. REV. 229, 339 (1994) (describing Cover as "the prime mover in the reintroduction of Jewish values to contemporary American legal discourse"); Steven L. Winter, The Cognitive Dimension of the Agon Between Legal Power and Narrative Meaning, 87 MiCH. L. REV. 2225, 2225 n.3 (1989) (acknowledging "the liberating effect" of Cover's work on the author's "sense of [his] own past" and stating that Cover's work has shown "how the intellectual abundance of these materials [i.e., Jewish sources] can be a profound source of analytic insight"); Stephen Wizner, Repairing the World Through Law: A Reflection on Robert Cover's Social Activism, 8 CARDOZO STUD. L. \& LITERATURE 1 (1996); Stephen Wizner, Tributes to Robert M. Cover, 96 YALE L.J. 1707 (1987).

${ }^{76}$ See, e.g., Robert M. Cover, Bringing the Messiah Through Law: A Case Study, in NOMOS XXX: Religion, MORALITY, AND tHe LaW (J. Roland Pennock \& John W. Chapman eds., 1988); Robert M. Cover, The Folktales of Justice: Tales of Jurisdiction, 14 CAP. U. L. REv. 179 (1985); Robert M. Cover, Obligation: A Jewish Jurisprudence of the Social Order, 5 J.L. \& RELIGION 65 (1987) [hereinafter Cover, Obligation]; Robert M. Cover, The Supreme Court, 1982 Term-Foreword: Nomos and Narrative, 97 HARV. L. REV. 4 (1983) [hereinafter Cover, Nomos and Narrative].

$\pi$ See, e.g., Cover, Nomos and Narrative, supra note 76, at 12.

${ }^{78}$ See, e.g., Cover, Obligation, supra note 76. 